Krzysztof DUDZIK, Adam CHARCHALIS

Gdynia Maritime University (Uniwersytet Morski w Gdyni)

\title{
POSSIBILITY ANALYSIS OF USING ACOUSTIC EMISSION FOR MONITORING TECHNICAL CONDITION OF COMPRESSED AIR INSTALLATION OF 3AL25/30 ENGINE
}

\author{
Analiza możliwości zastosowania emisji akustycznej do \\ monitorowania stanu technicznego instalacji sprężonego \\ powietrza silnika 3AL25/30
}

\begin{abstract}
This paper presents the methodology and research results of monitoring of compressed air starting system of 3AL25/30 engine placed in Maritime Engineering Faculty of Gdynia Maritime University. Research was carried out using a set of acoustic emission Vallen System. Analysis of recorded parameters revealed leakage in the installation damage of one of the valves. The test results indicate that the AE method can be useful for monitoring the technical condition of pressure systems of engines and devices in a ship's engine room during normal operation as an on-line system.
\end{abstract}

Keywords: acoustic emission, diagnostics, monitoring, compressed air installation

Streszczenie: $W$ artykule przedstawiono metodykę oraz wyniki badań monitorowania systemu startowego sprężonego powietrza silnika 3AL25/30, będacego na wyposażeniu Laboratorium Siłowni Okrętowych Wydziału Mechanicznego Uniwersytetu Morskiego $w$ Gdyni. Badania przeprowadzono za pomoca zestawu do rejestracji $i$ analizy emisji akustycznej Vallen System. Analiza zarejestrowanych sygnałów wykazała nieszczelność w instalacji-uszkodzenie jednego z zaworów. Wyniki badań wskazują, że metoda EA może być przydatna do monitorowania stanu technicznego instalacji ciśnieniowych silników i urządzeń w siłowni okrętowej podczas normalnej pracy w czasie rzeczywistym.

Słowa kluczowe: emisja akustyczna, diagnostyka, monitoring, instalacja sprężonego powietrza 


\section{Introduction}

The starting system of a ship engine is usually a compressed air system. For safety reasons, according to the requirements of classification societies, the capacity of the system must ensure the possibility of carrying out at least 6 starts. The overall condition of the entire starting system, especially its tightness, is very important.

One of the methods used for monitoring condition of different installations, e.g. compressed air engine starting system is the acoustic emission (AE) method $[2,7]$. According to the definition acoustic emission is an evanescent elastic wave, which is the result of rapid release of the energy stored in the material by propagating a micro-damage (increase in micro-cracks, the movement of groups of dislocations) in the material or by a process (friction, leakage, etc.) [5-7, 11]. The typical frequency range of the acoustic emission is normally determined within 20 $\mathrm{kHz}-2 \mathrm{MHz}[8]$.

The acoustic waves propagate in all directions from the source, thus can be recorded by one or more sensors mounted on an object or component. During the propagation of the $\mathrm{AE}$ waves they are damped by several physical effects. Therefore the waves can only be detected within a limited distance. These distance dependents on many factors, mainly on properties of the material, the geometry of the object and the level of interference from background noise [10]. AE signal can be characterized by parameters such as: amplitude, frequency, energy, rise time, duration, number of exceedances of the threshold of discrimination - hits, RMS of the signal, etc [1, 3-7]. Examples of AE signals are shown in figs. 1 and 2.

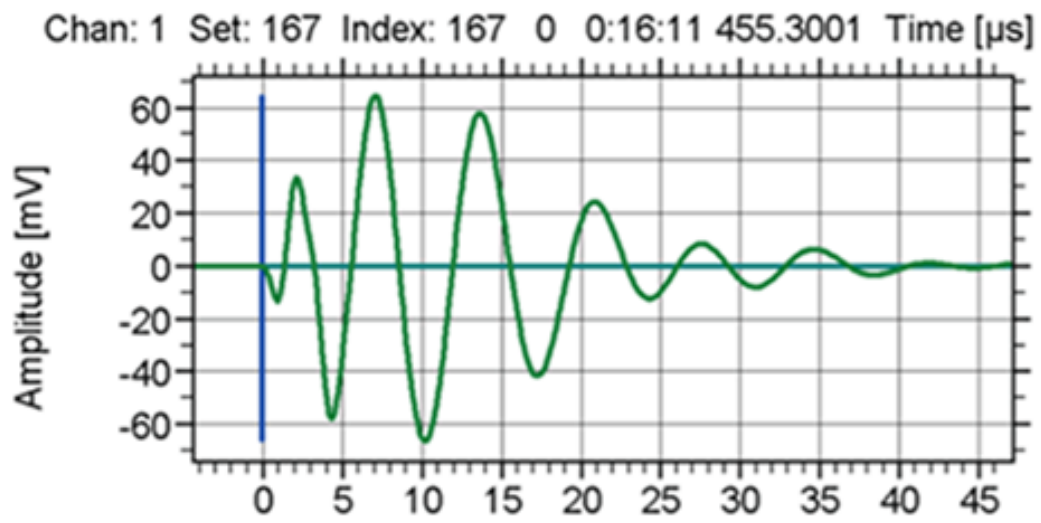

Fig. 1. Example of typical acoustic emission signal - burst signal [11] 


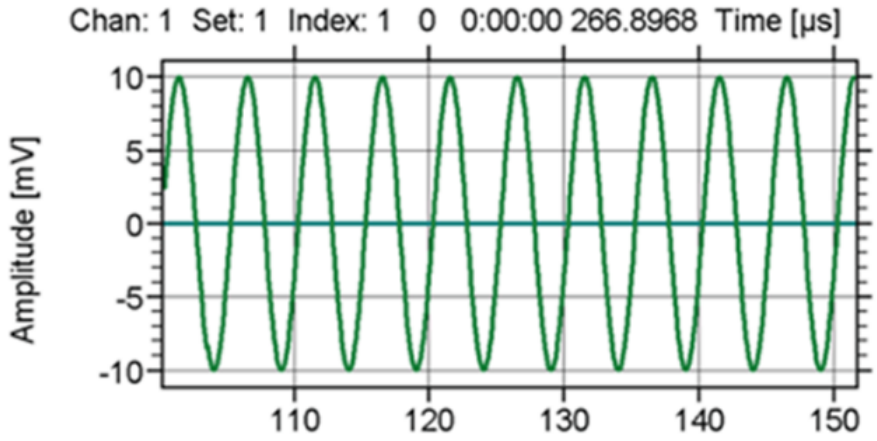

Fig. 2. Example of typical acoustic emission signal - b) continuous signal [11]

Acoustic Emission is a passive non-destructive method. Its main advantages are:

- high sensitivity,

- the possibility of continuously research,

- the possibility to locate the source of the AE signals (damages, leaks, etc.),

- the possibility of carrying out research without having to shut down equipment out of service [2].

The stimulus causing the release of energy and the formation of elastic waves can be: load operation, environment, temperature change, and the processes which are accompanied by $\mathrm{AE}$ changes both at the micro and the macro scale, such as: cracks, friction, plastic deformation, corrosion, leaks, structural and phase changes, chemical reactions, delamination, cracking of the fibers and matrix in composites, etc. $[1,8]$.

\section{The research methodology}

The research was carried out on a part of starting system of 3AL25/30 laboratory engine - compressed air tank, placed in Maritime Engineering Faculty of Gdynia Maritime University. This is 3-cylinder medium speed self-ignition engine, which drives electro-generator.

Research of acoustic emission during monitoring compressed air tank was performed using a kit consisting of 4-channel signal recorder type AMSY 6 and two measuring modules ASIP-2/S from Vallen System. The kit includes preamplifier with a frequency range of $20 \mathrm{kHz}-1 \mathrm{MHz}$ and the strengthening of $34 \mathrm{~dB}$ and a sensor signal measurement AE, VS $150 \mathrm{M}$, with a frequency range of 100 $450 \mathrm{kHz}$. View of laboratory engine used in research is presented in fig. 3 while the laboratory stand is shown in fig. 4. 


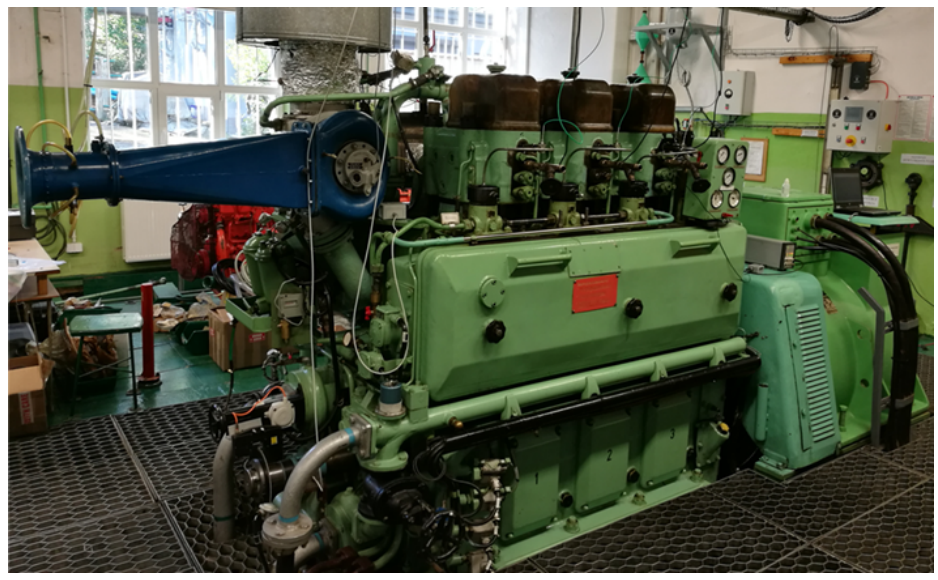

Fig. 3. The view of 3 AL25/30 engine used in research

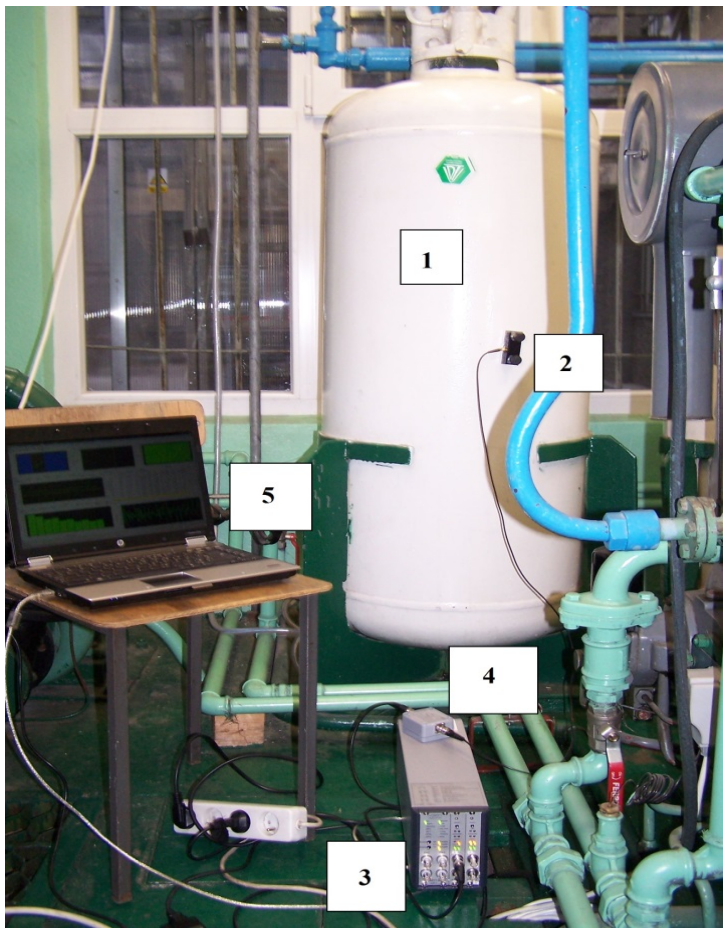

Fig. 4. The view of compressed air tank during research: 1 - compressed air tank, 2 - AE sensor with magnetic holder, 3 - AE recorder, 4 - preamplifier, 5 - computer

The AE system includes a data recording module $-8 \mathrm{MB}$ per channel and software for recording and analyzing data. The sensor was mounted on the side 
surface of the tank by means of a magnetic holder MAG4M - dedicated to used sensor. Between the sensor and the surface the coupling fluid was used.

The tests were carried out during the normal operation of the system. The air pressure in the tank was $3 \mathrm{MPa}$. A total of 6 measurements were made. The sensor was placed twice in each position: near the bottom, in the middle and close to the top of the tank.

During the study recorded a number of parameters which were analyzed. These parameters were e.g.: amplitude, number of events - hits, energy, RMS of the signal. For recording $\mathrm{AE}$ data was used Vallen Acquisition software and for analysing VisualAE software.

\section{The research results}

The results of acoustic emission test of the compressed air tank, in the form of average values and their standard deviation of chosen parameters indicative of $\mathrm{AE}$ signals, are presented in tab. 1 .

Table 1

Values of chosen parameters recorded during test on laboratory stand

\begin{tabular}{||l|c|c|c||}
\hline \multicolumn{1}{|c|}{ AE parameter } & $\begin{array}{c}\text { A } \\
{[\mathrm{dB}]}\end{array}$ & $\begin{array}{c}\text { RMS } \\
{[\boldsymbol{\mu V}]}\end{array}$ & $\begin{array}{c}\text { Counts } \\
{[-]}\end{array}$ \\
\hline mean value & 66.7 & 142.6 & 10050 \\
\hline std. dev. & 1.5 & 0.2 & 70 \\
\hline
\end{tabular}

Example of graph, showing the number of events and their amplitude as a function of time, recorded during the study, is presented in fig. 5. The sensor was mounted near the top of the tank and the measure was repeated two times.

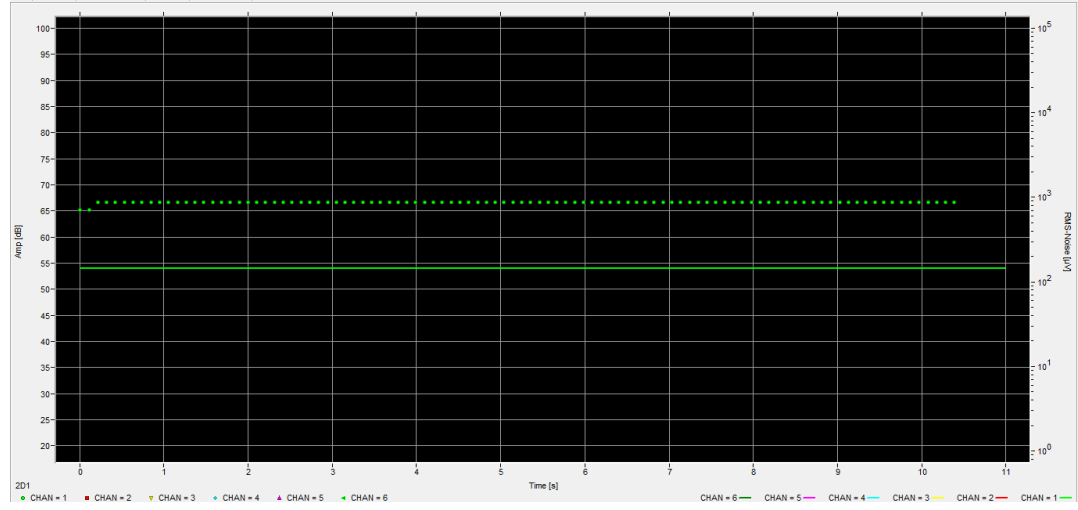

Fig. 5. Chart of number of hits and their amplitude changing as a function of time during leakage at the system 
The analysis of research results allows to determine character of phenomena generated AE signals. Continuous character of the signals may indicate a leakage in the installation. Figure 6 shows exemplary signal amplitude as a function of time recorded during research.

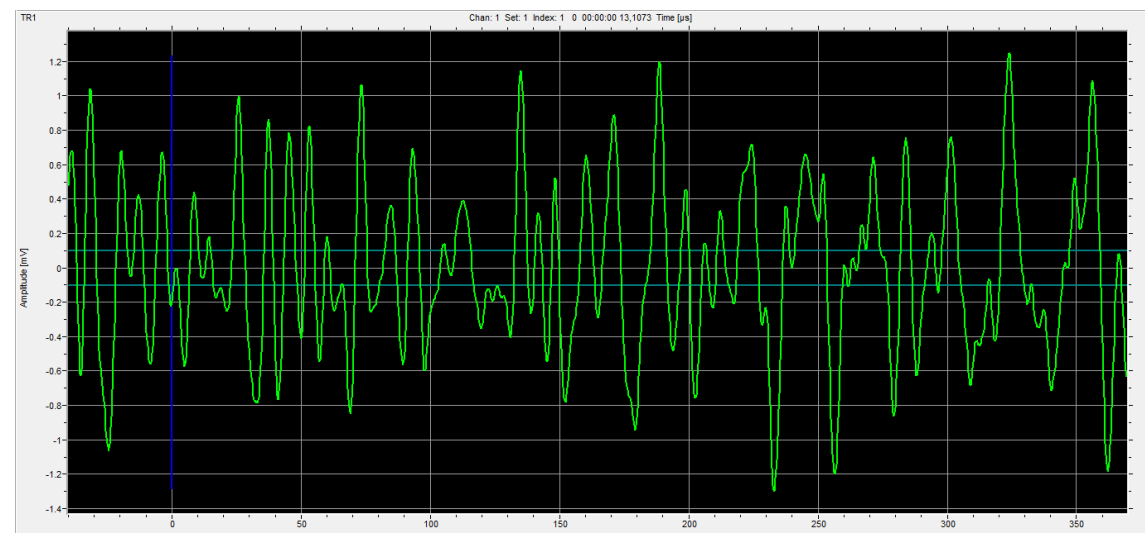

Fig. 6. An example of the signal recorded during leakage at the system: AE sampled signal

Additionally, analysis of recorded signals after FFT (Fast Fourier Transform) allows to define nature of the phenomenon on the basis of their frequency. Relatively low frequency (the signal frequency range is between $40-185 \mathrm{kHz}$ ) confirms a leakage in tested system. Figure 7 shows exemplary signal amplitude as a function of the frequency recorded during research.

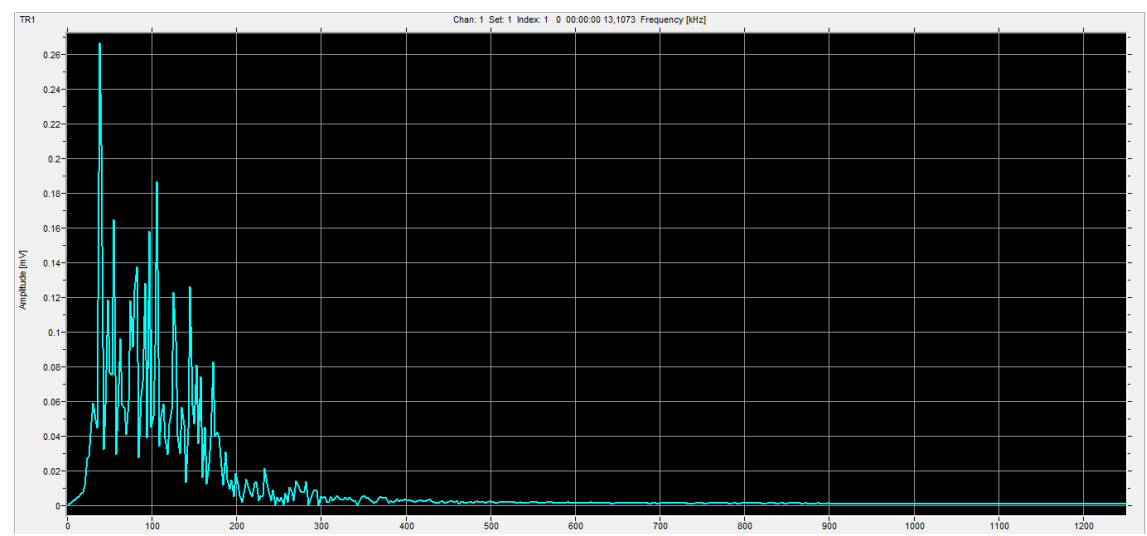

Fig. 7. An example of the signal recorded during leakage at the system: signal after FFT analysis 
The leakage may have been caused by a damaged tank, pipeline or valve. After the inspection, damage of the valve placed in the tank head was detected. After its repair, AE measurements were made again. In this case not registered any signals that might indicate leaks as well as active corrosion processes. On this basis, the good condition of the tested tank was found.

\section{Conclusions}

The starting system of a ship engine is usually a compressed air system. The overall condition of the entire starting system, especially its tightness, is very important. One of the methods used for monitoring condition of compressed air engine starting system is the acoustic emission (AE) method. It allows conducting tests without the necessity of shutting down the devices from operation, conducting continuous tests in real time as well as localizing the source of AE signals generated by damages, leaks, corrosion, etc.

The analysis of the research results of the acoustic emission generated during monitoring technical condition of compressed air tank indicated, that $\mathrm{AE}$ parameters of the highest diagnostic significance were: signal amplitude, RMS and number of events - hits.

Recorded during research, continuous signal with a constant amplitude (approx. $67 \mathrm{~dB}$ ) and a relatively low frequency $(40-185 \mathrm{kHz})$ may indicate a leak in the installation. On the basis of the AE tests, the tank head was inspected, where the valve damage was revealed. The detected valve defect allowed to take appropriate repairing processes and thus eliminate the leaks in the compressed air system.

AE measurements carried out after leaking valve repair, showed good condition of the tank and other elements of the compressed air starting system. No signals characteristic for leaks and active corrosive processes were registered, which indicates their lack in the tested installation.

The research results allowed to draw the following conclusion - AE method can be useful for monitoring the technical condition of pressure systems of engines and devices in a ship's engine room during normal operation. 


\section{References}

1. Baran I.: Identyfikacja uszkodzeń korozyjnych zbiorników na paliwa płynne metodą emisji akustycznej [Identification of corrosion damages of liquid fuel tanks by acoustic emission]. PhD thesis, Kraków 2013.

2. Baran I., Nowak M., Schmidt J., Ono K.: Potentials of AE application in testing industrial pipelines. Advances in Acoustic Emission, USA, 2007.

3. Bejger A.: Zastosowanie fal sprężystych emisji akustycznej do diagnozowania układów wtryskowych okrętowych silników spalinowych [Application of elastic waves of acoustic emission to diagnose injection systems of marine combustion engines]. Fotobit, Kraków 2012.

4. Dudzik K., Charchalis A.: Wykorzystanie emisji akustycznej do diagnozowania wtryskiwacza silnika 3AL25/30 [The use of acoustic emission for the diagnosis of 3AL25/30 engine fuel injector]. Logistyka, No. 3, 2015.

5. Dudzik K.: The possibility of application acoustic emission method for controlling friction stir welding of AW-5083 aluminium alloy sheets, In METAL 2017: 26th International Conference on Metallurgy and Materials. Ostrava: TANGER, 2017.

6. Dudzik K.: Monitoring of FSW process using acoustic emission method, In METAL 2018: 27th International Conference on Metallurgy and Materials. Ostrava: TANGER, 2018.

7. Malecki I., Ranachowski J. (eds.): Emisja Akustyczna, źródła, metody, zastosowania [Acoustic Emission, sources, methods, applications]. Pascal Publications, Warszawa 1994.

8. Vallen Systeme, AMSY-6 Handbook, System description, Germany, 2010.

9. Ziegler B.: Contribution of acoustic emission into optimal bearing lubrication. Journal of KONES, Warszawa 2007.

10. Ziegler B.: Zastosowanie emisji akustycznej do identyfikacji warunków smarowania łożysk ślizgowych [Application of acoustic emission to identify lubricating conditions of slide bearings]. PhD thesis, Koszalin 2009.

11. Ziegler B., Miszczak A.: Acoustic emission as a friction force indicator after test stands experiments. Journal of KONES, Warszawa 2007. 


\section{ANALIZA MOŻLIWOŚCI ZASTOSOWANIA EMISJI AKUSTYCZNEJ DO MONITOROWANIA STANU TECHNICZNEGO INSTALACJI SPRĘŻONEGO POWIETRZA SILNIKA 3AL25/30}

\section{Wprowadzenie}

System startowy silnika okrętowego to zazwyczaj system sprężonego powietrza. Ze względów bezpieczeństwa, zgodnie z wymaganiami towarzystw klasyfikacyjnych, pojemność układu musi zapewnić możliwość przeprowadzenia co najmniej sześciu rozruchów. Ogólny, dobry stan techniczny systemu startowego, szczególnie jego szczelność, jest bardzo ważny. Jedną z metod stosowanych do monitorowania stanu technicznego różnych instalacji, np. instalacji sprężonego powietrza układu rozruchowego silnika okrętowego, jest metoda emisji akustycznej (AE) [2, 7].

Zgodnie z definicją, emisja akustyczna to zanikająca fala sprężysta, będąca efektem gwałtownego wyzwolenia energii nagromadzonej w materiale przez propagujące się mikrouszkodzenia (wzrost mikroszczelin, ruch grup dyslokacji) w materiale lub przez proces (tarcie, przecieki, itp.) [5-7, 11]. Zakres częstotliwości typowy dla emisji akustycznej najczęściej określany jest w przedziale $20 \mathrm{kHz}-2 \mathrm{MHz}$ [8].

Fale akustyczne propagują we wszystkich kierunkach od źródła, mogą być więc rejestrowane przez jeden lub więcej czujników zamocowanych na obiekcie lub elemencie. W czasie propagacji fale AE ulegają wyttumieniu, co ogranicza dystans, na jakim mogą one być wykrywalne. Dystans ten jest uzależniony od wielu czynników, w tym przede wszystkim od własności materiału, geometrii obiektu i poziomu zakłóceń pochodzących z tła akustycznego [9]. Sygnał emisji akustycznej może być charakteryzowany takimi parametrami jak: amplituda, częstotliwość, energia, czas narastania sygnału, czas trwania zdarzenia, liczba przekroczeń progu dyskryminacji - liczba zdarzeń, wartość skuteczna sygnału RMS i inne [1,3-7].

Metoda AE jest pasywną metodą nieniszczącą. Główne jej zalety to:

- wysoka czułość,

- możliwość prowadzenia badań bez konieczności wyłączania urządzeń z eksploatacji,

- możliwość prowadzenia badań ciągłych, 
- możliwość lokalizacji źródła sygnałów AE generowanych przez uszkodzenia, przecieki itp. [2].

Bodźcem wywołującym wyzwolenie energii i powstawanie fal sprężystych może być działanie obciążenia, środowiska czy zmiana temperatury, a procesy, którym towarzyszy emisja akustyczna, to zarówno zmiany w skali mikro i makro, m.in.: pęknięcia, tarcie, odkształcenia plastyczne, korozja, nieszczelności, przemiany strukturalne i fazowe, reakcje chemiczne, delaminacja, pękanie włókien i osnowy w kompozytach itd. [1, 9]. Przykładowe sygnały AE przedstawiono na rys. 1 i 2.

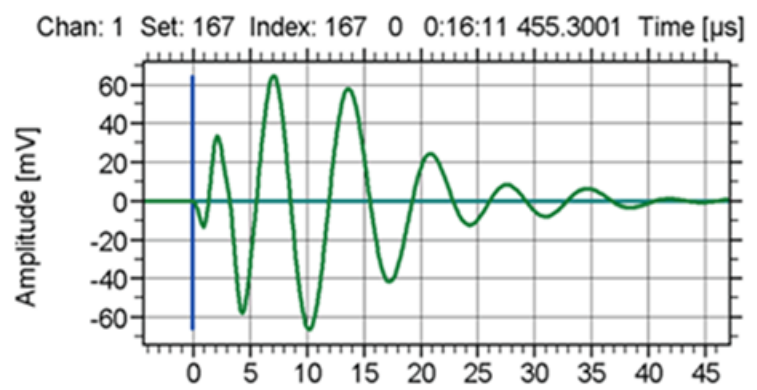

Rys. 1. Przykładowy wykres przedstawiający dyskretny sygnał AE [11]

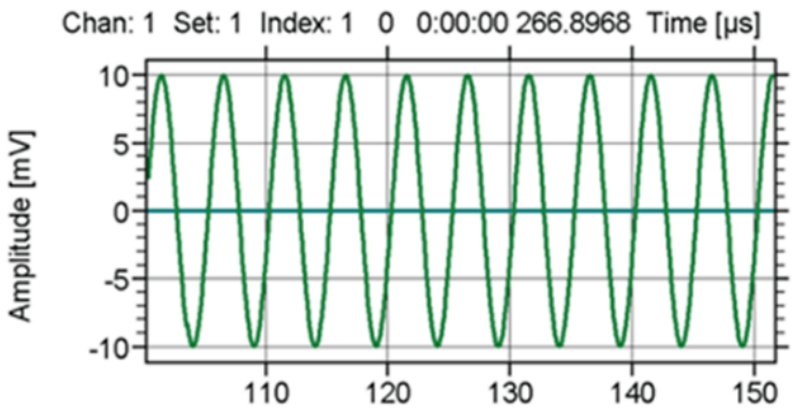

Rys. 2. Przykładowy wykres przedstawiający ciągły sygnał AE [11]

\section{Metodyka badań}

Badania zostały przeprowadzone na wybranym elemencie - zbiorniku sprężonego powietrza, systemu startowego silnika laboratoryjnego 3AL 25/30, stanowiącego wyposażenie Wydziału Mechanicznego Uniwersytetu Morskiego w Gdyni. Silnik ten to 3-cylindrowa średnioobrotowa jednostka o zapłonie samoczynnym, napędzająca prądnicę. 
Badania emisji akustycznej (AE) towarzyszącej procesowi monitorowania stanu technicznego zbiornika sprężonego powietrza przeprowadzono za pomocą zestawu składającego się z 4-kanałowego rejestratora sygnału typu AMSY 6 oraz dwóch modułów pomiarowych ASIP-2/S firmy Vallen System. W skład zestawu wchodzi przedwzmacniacz o zakresie częstotliwości $20 \mathrm{kHz}-1 \mathrm{MHz}$ i wzmocnieniu $34 \mathrm{~dB}$ oraz czujnik pomiaru sygnału AE, typu VS $150 \mathrm{M}$, o zakresie częstotliwości $100-450 \mathrm{kHz}$. Widok silnika laboratoryjnego wykorzystanego w badaniach przedstawiono na rys. 3, natomiast stanowiska badawczego na rys. 4 .

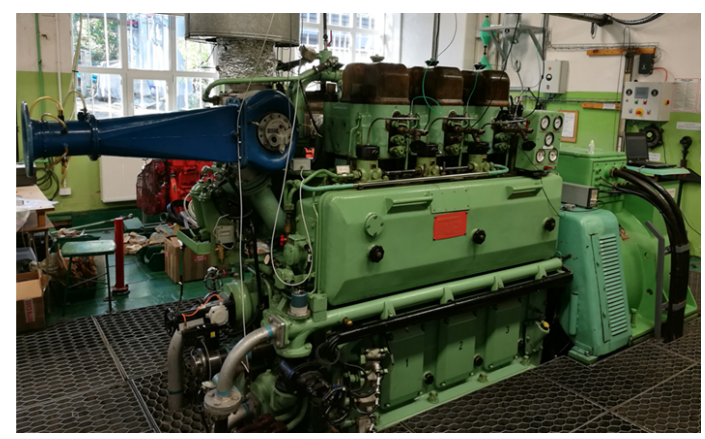

Rys. 3. Widok silnika 3AL25/30 wykorzystanego w badaniach

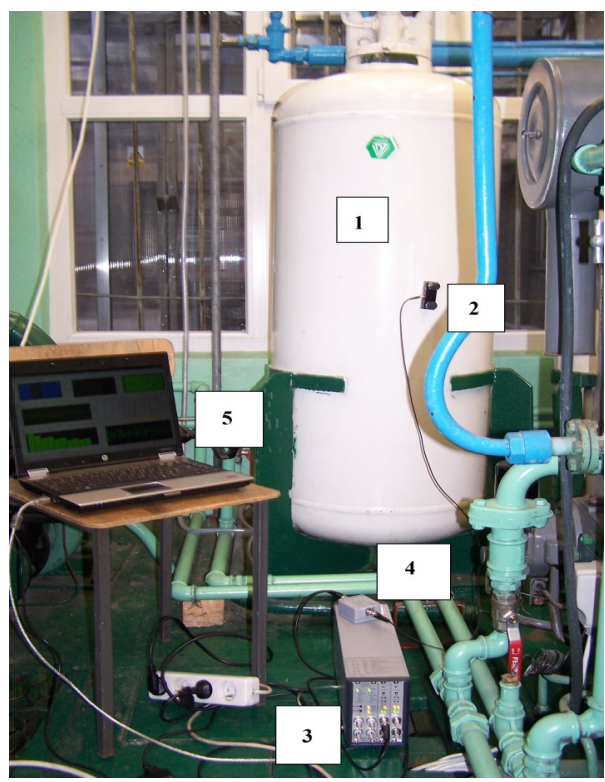

Rys. 4. Widok zbiornika sprężonego powietrza podczas badań: 1 - zbiornik sprężonego powietrza, 2 - czujnik AE z uchwytem magnetycznym, 3 - rejestrator, 4 przedwzmacniacz, 5 - komputer 
Układ zawiera moduł nagrywający dane po $8 \mathrm{MB}$ na każdy kanał oraz oprogramowanie do rejestracji i analizy danych AE. Czujnik zamontowano na powierzchni bocznej zbiornika za pomocą uchwytu magnetycznego MAG4M dedykowanego do używanego czujnika. Pomiędzy czujnikiem a powierzchnią zastosowano ciecz sprzęgającą.

Badania przeprowadzono podczas normalnej pracy układu. Ciśnienie powietrza w zbiorniku wynosiło $3 \mathrm{MPa}$. Łącznie wykonano sześć pomiarów. Czujnik umieszczano dwukrotnie w pozycjach: blisko dna, w środku zbiornika oraz w pobliżu jego głowicy.

Podczas badań rejestrowano wiele parametrów, które następnie poddano analizie. Tymi parametrami były m.in.: amplituda, liczba zdarzeń, energia, wartość skuteczna sygnału - RMS. Rejestrację przeprowadzono przy wykorzystaniu oprogramowania Vallen Acquisition, oraz program VisualAE do analizy wyników.

\section{Wyniki badań}

Wyniki badań monitorowania stanu technicznego zbiornika sprężonego powietrza, w formie wartości średnich i ich odchylenia standardowego, wybranych parametrów charakteryzujących sygnały emisji akustycznej, przedstawiono w tabeli 1.

Tabela 1

Wartości wybranych parametrów zarejestrowanych podczas badań

\begin{tabular}{||l|c|c|c||}
\hline \multicolumn{1}{|c|}{ AE parametr } & $\begin{array}{c}\mathbf{A} \\
{[\mathbf{d B}]}\end{array}$ & $\begin{array}{c}\mathbf{R M S} \\
{[\boldsymbol{\mu} \mathbf{V}]}\end{array}$ & $\begin{array}{c}\text { Liczba zdarzeń } \\
{[-]}\end{array}$ \\
\hline wartość średnia & 66,7 & 142,6 & 10050 \\
\hline odchylenie std. & 1,5 & 0,2 & 70 \\
\hline
\end{tabular}

Przykładowy wykres, przedstawiający liczbę zdarzeń i ich amplitudę w funkcji czasu, zarejestrowany podczas badań, przedstawiono na rys. 5. Czujnik był zamontowany w górnej części zbiornika a badanie powtórzono dwa razy. 


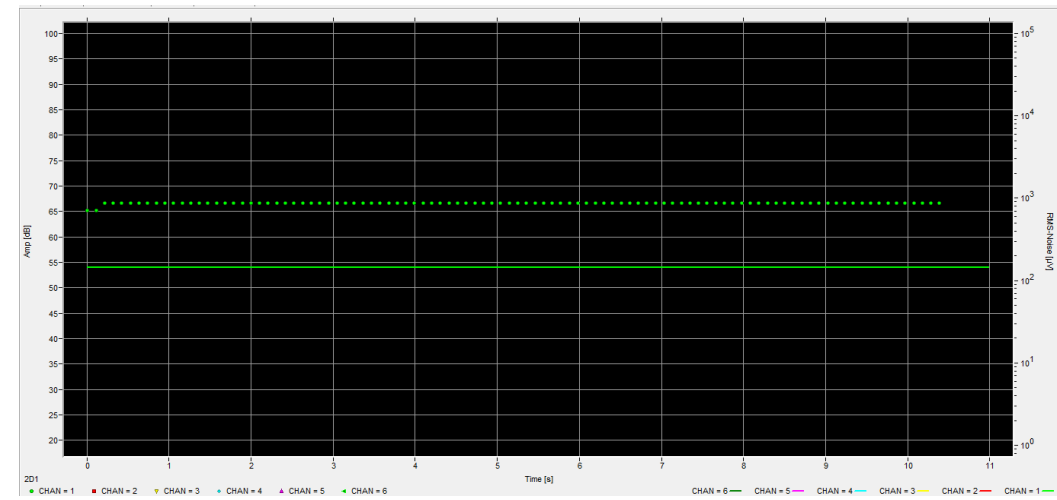

Rys. 5. Wykres przedstawiający liczbę zdarzeń i ich amplitudę w funkcji czasu podczas nieszczelności w układzie

Analiza wyników badań pozwoliła określić charakter zjawiska generującego sygnały AE. Ciągły charakter sygnałów może wskazywać na nieszczelność w instalacji. Rysunek 6 przedstawia przykładową zmianę amplitudy sygnału w funkcji czasu, zarejestrowaną w czasie badań.

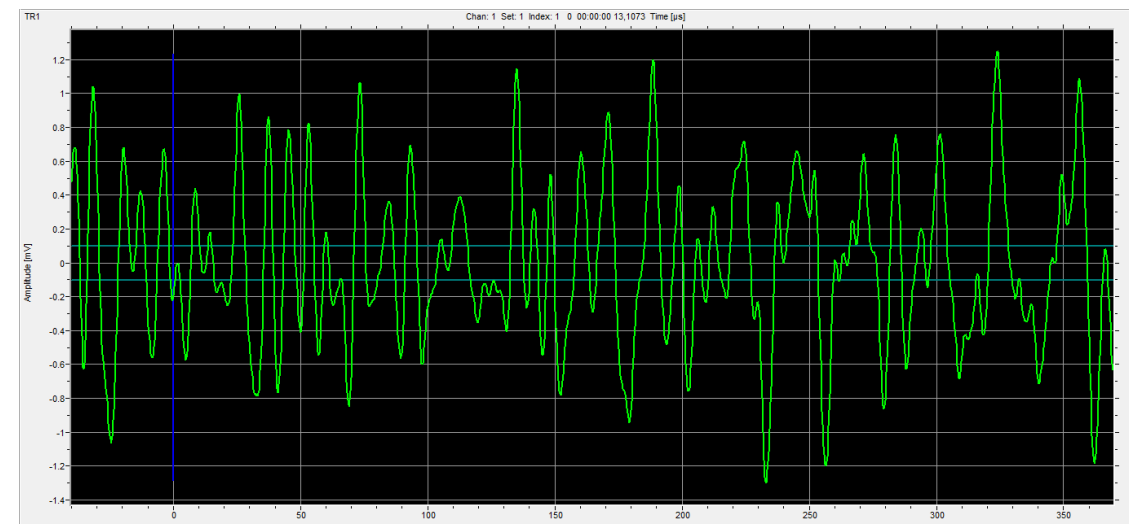

Rys. 6. Przykładowy sygnał zarejestrowany podczas nieszczelności systemu - amplituda sygnału AE w funkcji czasu

Dodatkowo, przeprowadzona analiza FFT (szybka transformata Fouriera) umożliwiała określenie charakteru zjawiska na podstawie jego częstotliwości. Stosunkowo niska częstotliwość (częstotliwość sygnału zmieniała się w granicach 40-185 kHz) potwierdziła nieszczelność testowanego systemu.

Na rys. 7 przedstawiono przykładowy wykres zmiany amplitudy w funkcji częstotliwości sygnału zrejestrowanego podczas badań. 


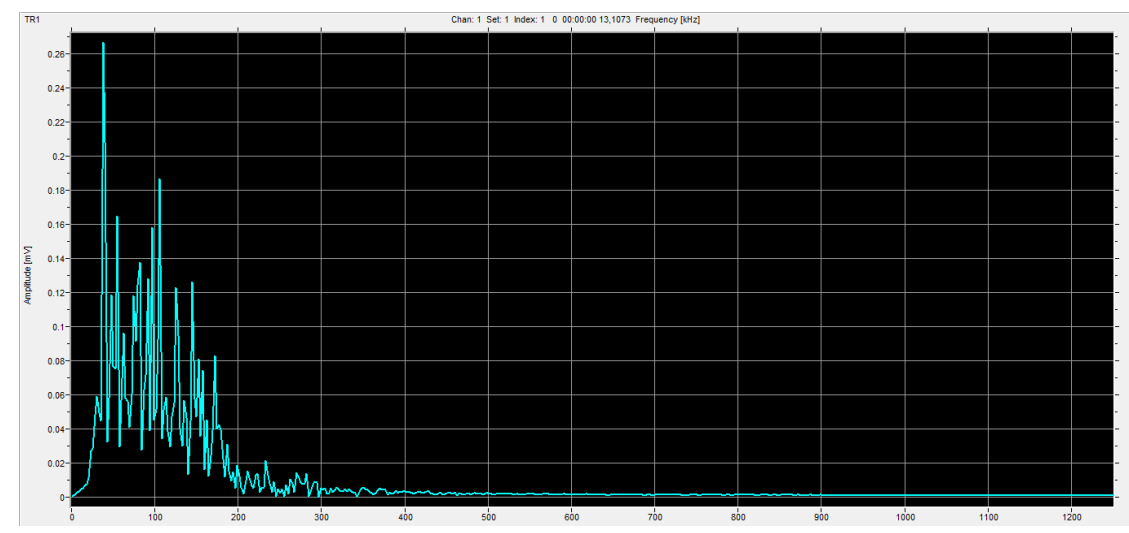

Rys. 7. Przykładowy sygnał zarejestrowany podczas nieszczelności systemu - amplituda sygnału AE w funkcji częstotliwości

Nieszczelność może być spowodowana uszkodzeniem zbiornika, rurociągu lub zaworu. Po przeprowadzeniu inspekcji zdiagnozowano uszkodzenie zaworu w głowicy zbiornika. Po jego naprawie ponownie wykonano pomiary metodą emisji akustycznej. W tym przypadku nie zarejestrowano żadnych sygnałów mogących wskazywać na przecieki, jak również na aktywne procesy korozyjne. $\mathrm{Na}$ tej podstawie stwierdzono dobry stan badanego zbiornika.

\section{Wnioski}

System startowy silnika okrętowego to zazwyczaj system sprężonego powietrza. Dobry stan techniczny systemu startowego, szczególnie jego szczelność, jest bardzo ważny. Jedną z metod stosowanych do monitorowania stanu technicznego instalacji sprężonego powietrza układu rozruchowego silnika okrętowego jest metoda emisji akustycznej. Pozwala ona na prowadzenie badań bez konieczności wyłączania urządzeń, prowadzenie badań ciągłych w czasie rzeczywistym, jak również lokalizowanie źródeł sygnałów AE generowanych przez uszkodzenia, przecieki, korozję itp.

Analiza wyników badań emisji akustycznej generowanej podczas monitorowania stanu technicznego zbiornika sprężonego powietrza wykazała, że parametrami AE o największym znaczeniu diagnostycznym były: amplituda, wartość skuteczna RMS i liczba przekroczeń progu dyskryminacji - liczba zdarzeń.

Zarejestrowany ciągły sygnał o stałej amplitudzie (ok. $67 \mathrm{~dB}$ ) i stosunkowo niskiej częstotliwości (40-185 kHz) może świadczyć o nieszczelności w instalacji. $\mathrm{Na}$ podstawie badań AE przeprowadzono inspekcję głowicy zbiornika, gdzie 
ujawniono uszkodzenie zaworu. Wykryta usterka zaworu umożliwiła podjęcie odpowiednich działań naprawczych, a tym samym wyeliminowanie nieszczelności w układzie sprzężonego powietrza.

Pomiary AE przeprowadzone po naprawie nieszczelnego zaworu wykazały dobrą kondycję zbiornika i pozostałych elementów systemu startowego sprężonego powietrza. Nie zarejestrowano żadnych sygnałów charakterystycznych dla przecieków i aktywnych procesów korozyjnych, co wskazuje na ich brak w badanej instalacji.

Wyniki badań pozwoliły wyciągnąć następujący wniosek: metoda EA może być przydatna do monitorowania stanu technicznego instalacji ciśnieniowych silników i urządzeń w siłowni okrętowej podczas normalnej pracy w czasie rzeczywistym.

\section{Literatura}

1. Baran I.: Identyfikacja uszkodzeń korozyjnych zbiorników na paliwa płynne metodą emisji akustycznej. Rozprawa doktorska, Kraków 2013.

2. Baran I., Nowak M., Schmidt J., Ono K.: Potentials of AE application in testing industrial pipelines. Advances in Acoustic Emission, USA, 2007.

3. Bejger A.: Zastosowanie fal sprężystych emisji akustycznej do diagnozowania układów wtryskowych okrętowych silników spalinowych. Fotobit, Kraków 2012.

4. Dudzik K., Charchalis A.: Wykorzystanie emisji akustycznej do diagnozowania wtryskiwacza silnika 3AL25/30. Logistyka, No. 3, 2015.

5. Dudzik K.: The possibility of application acoustic emission method for controlling friction stir welding of AW-5083 aluminium alloy sheets, In METAL 2017: 26th International Conference on Metallurgy and Materials. Ostrava: TANGER, 2017.

6. Dudzik K.: Monitoring of FSW process using acoustic emission method, In METAL 2018: 27th International Conference on Metallurgy and Materials. Ostrava: TANGER, 2018.

7. Malecki I., Ranachowski J. (red.): Emisja Akustyczna, źródła, metody, zastosowania. Pascal Publications, Warszawa 1994.

8. Vallen Systeme, AMSY-6 Handbook, System description, Germany, 2010.

9. Ziegler B.: Contribution of acoustic emission into optimal bearing lubrication. Journal of KONES, Warszawa 2007.

10. Ziegler B.: Zastosowanie emisji akustycznej do identyfikacji warunków smarowania łożysk ślizgowych. Rozprawa doktorska, Koszalin 2009.

11. Ziegler B., Miszczak A.: Acoustic emission as a friction force indicator after test stands experiments. Journal of KONES, Warszawa 2007. 